\title{
Functional characterization of mouse $\alpha 4 \beta 2$ nicotinic acetylcholine receptors stably expressed in HEK293T cells
}

\author{
Mark S. Karadsheh,* M. Salman Shah,* Xin Tang, $\dagger$ Robert L. Macdonald $\dagger$ and Jerry A. Stitzel $\ddagger$ \\ *Department of Pharmacology, University of Michigan Medical School, Ann Arbor, Michigan, USA \\ $\dagger$ †epartment of Neurology, Vanderbilt University Medical School, Nashville, Tennessee, USA \\ $\$$ Department of Integrative Physiology and Institute for Behavioral Genetics, University of Colorado, Boulder, Colorado, USA
}

\begin{abstract}
Mouse $\alpha 4 \beta 2$ nicotinic acetylcholine receptors (nAchRs) were stably expressed in HEK293T cells. The function of this stable cell line, termed mm $\alpha 4 \beta 2$, was assessed using an aequorinbased luminescence method that measures agonist-evoked changes in intracellular calcium. Agonist-elicited changes in intracellular calcium were due primarily to direct entry of calcium through the $\alpha 4 \beta 2$ channel, although release of calcium from intracellular stores contributed $\sim 28 \%$ of the agonistevoked response. Agonist pharmacologies were very similar between the mma4 $\beta 2$ cells and most cell lines that stably express human $\alpha 4 \beta 2 \mathrm{nAchRs}$. Based on agonist profiles and sensitivity to the antagonist dihydro- $\beta$-erythroidine (DH $\beta E$ ), the predominant $\alpha 4 \beta 2 \mathrm{nAchR}$ expressed in the mm $\alpha 4 \beta 2$ cells exhibits a pharmacology that most resembles the
\end{abstract}

DH $\beta E$-sensitive component of ${ }^{86} \mathrm{Rb}^{+}$efflux from mouse brain synaptosomes. However, when evaluated with the aequorin assay, the mm $\alpha 4 \beta 2 \mathrm{nAchR}$ was found to be atypically sensitive to blockade by the presumed $\alpha 7$-selective antagonist methyllycaconitine (MLA), exhibiting an $\mathrm{IC}_{50}$ value of $31 \pm 0.1 \mathrm{~nm}$. Similar $\mathrm{IC}_{50}$ values have been reported for the MLA inhibition of nicotine-stimulated dopamine release, a response that is mediated by $\beta 2$-subunit-containing nAchRs and not $\alpha 7$-subunit-containing nAchRs. Consequently, at low nanomolar concentrations, MLA may not be as selective for $\alpha 7$ containing nAchRs as previously thought.

Keywords: aequorin, calcium, heterologous expression, luminescence, methyllycaconitine.

J. Neurochem. (2004) 91, 1138-1150.
Alterations in intracellular calcium levels in neurons can affect a wide range of cellular processes including changes in gene expression, synaptic plasticity, neurotransmission and neurotransmitter release (for review, see Berridge 1998). Changes in intracellular calcium levels in neurons and glia can arise from the entry of calcium via ligand- and voltagegated ion channels, as well as from the release of calcium from distinct intracellular stores. Neuronal nicotinic acetylcholine receptors (nAchRs), like ionotropic glutamate receptors, are ligand-gated ion channels that exhibit high permeability to calcium (Vernino et al. 1992; Bertrand et al. 1993; Seguela et al. 1993; Role and Berg 1996; Ragozzino et al. 1998). Assembled from distinct combinations of subunits of the neuronal nAchR subunit family, numerous nAchR subtypes are expressed in the brain (Lindstrom 2003). The neuronal nAchR subunit family includes nine $\alpha$ subunits, designated $\alpha 2-\alpha 10$ and three $\beta$ subunits designated $\beta 2-\beta 4$. The nAchR subtype that exhibits the greatest calcium permeability relative to sodium is the $\alpha 7$ homomeric nAchR
(Bertrand et al. 1993; Seguela et al. 1993; Castro and Albuquerque 1995). Another nAchR subtype that is calcium permeable is the subtype composed of $\alpha 4$ and $\beta 2$ subunits (Vernino et al. 1992; Ragozzino et al. 1998).

The $\alpha 4 \beta 2 \mathrm{nAchR}$ is the most abundant nAchR subtype expressed in the brain, and studies have demonstrated that this receptor subtype is located presynaptically on

Received April 28, 2004; revised manuscript received July 22, 2004; accepted July 28, 2004.

Address correspondence and reprint requests to Jerry Stitzel, Ph.D., Institute for Behavioral Genetics, University of Colorado, UCB 447, Boulder, CO 80309-0447, USA. E-mail: Stitzel@colorado.edu

Abbreviations used: A85380, 3-(2-(S)-azetidinylmethoxy) pyridine dihydrochloride; Ach, acetylcholine; DEC, decamethonium; DH $\beta E$, dihydro- $\beta$-erythroidine; DMEM, Dulbecco's modified Eagle's medium; DMPP, dimethylphenylpiperazinium iodide; HEX, hexamethonium; MCC, methylcarbamylcholine chloride; MEC, mecamylamine; MLA, methyllycaconitine; nAchR, nicotinic acetylcholine receptor; PBS, phosphate-buffered saline; TMA, tetramethylammonium chloride. 
GABAergic (Alkondon et al. 1996; Lu et al. 1998; Zhu and Chiappinelli 1999; Klink et al. 2001) and dopaminergic terminals (Grady et al. 1992; Klink et al. 2001; Champtiaux et al. 2002; Zoli et al. 2002). This nAchR subtype is elevated in brain tissue from smokers (Benwell et al. 1988; Breese et al. 1997) and reduced in brain tissue from Alzheimer's disease patients (Flynn and Mash 1986; Nordberg and Winblad 1986; Whitehouse et al. 1986). Rare alleles for the genes that encode the $\alpha 4$ and $\beta 2$ subunits have been identified in humans and are associated with autosomaldominant nocturnal frontal lobe epilepsy (Steinlein 2004 for review).

Like humans, mice chronically exposed to nicotine exhibit an increase in $\alpha 4 \beta 2$ nAchRs in brain (Marks et al. 1983). In addition, mice engineered to lack this nAchR subtype exhibit learning deficits (Picciotto et al. 1995), loss of the neuroprotective effect of nicotine on 6-OH DOPA lesions in the striatum (Ryan et al. 2001) and do not show reinforcement by nicotine (Epping-Jordan et al. 1999). Studies have also described a polymorphism in the mouse $\alpha 4$ subunit gene that is associated with functional differences in $\alpha 4 \beta 2 \mathrm{nAchRs}$ in mouse brain synaptosomes (Stitzel et al. 2001; Dobelis et al. 2002) and affects receptor function in a heterologous expression system (Kim et al. 2003). This polymorphism is associated with mouse strain differences in sensitivity to nicotine-induced seizures (Stitzel et al. 2000) and other responses to nicotine (Tritto et al. 2002; Butt et al. submitted), as well as individual differences in responsiveness to alcohol (Owens et al. 2003; Butt et al. 2004).

Owing to the heterogeneity of nAchRs in the brain, it is difficult to evaluate the pharmacology and cell biology of individual native nAchR subtypes. This complication limits the ability to assess how variations in receptor function of specific nAchR subtypes might contribute to such processes as addiction and disease. In an attempt to establish the pharmacology and cell biology of individual nAchR subtypes, several heterologous expression systems that stably express specific nAchR subtypes, including the a4ß2 nAchR subtype (Gopalakrishnan et al. 1996; Chavez-Noriega et al. 2000; Michelmore et al. 2002; Eaton et al. 2003; Nelson et al. 2003) have been developed. However, despite the increasing number of these nAchRexpressing cell lines, an extensive comparison of the pharmacology of receptor function between these cell lines and native $\alpha 4 \beta 2$ nAchRs has not been reported. In the data described here, HEK293T cells that exhibit stable expression of a functional mouse $\alpha 4 \beta 2 \mathrm{nAchR}$ are described. Agonist-evoked increases in intracellular calcium by eight agonists and inhibition of the agonistevoked response by five antagonists were assessed in this cell line. In addition, the mechanism of agonist-induced changes in intracellular calcium in this cell line was evaluated. Finally, in order to evaluate the similarity between heterologously expressed mouse $\alpha 4 \beta 2$ nAchRs and native mouse $\alpha 4 \beta 2$ nAchRs, the agonist and antagonist profiles of the mouse $\alpha 4 \beta 2$ cell line were compared with the pharmacological profiles of native $\alpha 4 \beta 2$ nAchRmediated ${ }^{86} \mathrm{Rb}^{+}$efflux from mouse brain thalamic synaptosomes.

\section{Materials and methods}

\section{Cell culture}

HEK293T cells were maintained at $37^{\circ} \mathrm{C}$ in a humidified, $5 \% \mathrm{CO}_{2}$ environment in Dulbecco's modified Eagle's medium (high glucose, no pyruvate) (DMEM), 10\% heat-inactivated fetal bovine serum and antibiotic/antimycotic ( $100 \mathrm{U} / \mathrm{mL}$ penicillin, $100 \mu \mathrm{g} / \mathrm{mL}$ streptomycin and $0.25 \mu \mathrm{g} / \mathrm{mL}$ amphotericin B). Culture reagents were purchased from either Biowhittaker (East Rutherford, NJ, USA) or Invitrogen (Carlsbad, CA, USA).

\section{Generation of a HEK293T cell line stably transfected with} mouse $\alpha \mathbf{4}$ and $\beta 2$ nAchR subunits

Mouse nAchR $\alpha 4$ and $\beta 2$ subunit cDNAs were introduced into the mammalian expression vectors pcDNA3.1zeo (Invitrogen) and pcDNA3.1hygro (Invitrogen), respectively, as previously described (Kim et al. 2003). For transfection, HEK293T cells were plated at a density of $5 \times 10^{6}$ cells $/ 100 \mathrm{~mm}$ dish in DMEM supplemented with $10 \%$ fetal bovine serum and antibiotic/antimycotic. The day following plating, the cells were transfected with the mouse $\alpha 4$ and $\beta 2$ cDNA constructs using LipoFectamine Plus Reagent (Invitrogen) according to the manufacturer's suggested protocol. The A529 variant of the mouse $\alpha 4$ cDNA (Kim et al. 2003) was used for the transfection. Approximately $48 \mathrm{~h}$ following transfection, the media was supplemented with $0.05 \mathrm{mg} / \mathrm{mL}$ zeocin (Invitrogen) and $0.25 \mathrm{mg} / \mathrm{mL}$ hygromycin sulfate in order to select for cells that had stably integrated the $\alpha 4$ and $\beta 2$ expression vectors, respectively. Following 1 week of selection with zeocin and hygromycin, the concentrations of these drugs were increased to 0.1 and $0.5 \mathrm{mg} / \mathrm{mL}$, respectively. The cells then were maintained under these conditions for $2-3$ additional weeks. After this drug selection period, the cells were trypsinized and transferred to a new culture vessel. The cells always were maintained under selection with $0.1 \mathrm{mg} / \mathrm{mL}$ zeocin and $0.5 \mathrm{mg} / \mathrm{mL}$ hygromycin.

\section{Isolation of stable transfectants enriched for surface nAchR expression}

Pooled, stably transfected cells were removed from a near confluent $75 \mathrm{~cm}^{2}$ flask by gentle aspiration with phosphate-buffered saline (PBS) and transferred to a $5 \mathrm{~mL}$ sterile polypropylene tube. Following centrifugation at $4^{\circ} \mathrm{C}$ for $5 \mathrm{~min}$ at $800 \mathrm{~g}$, the PBS was removed and the cells were resuspended at a density of $5 \times 10^{6}$ cells $/ \mathrm{mL}$ in PBS supplemented with $2 \%$ heat-inactivated fetal bovine serum and $0.05 \%$ sodium azide (flow buffer). The antia4specific monoclonal antibody mAb299 (Covance, Berkeley, CA, USA) (Whiting and Lindstrom 1988) was added to the cells at a $1 / 500$ dilution and the cells were incubated for $1 \mathrm{~h}$ at $4^{\circ} \mathrm{C}$ with gentle rocking. After incubation with mAb299, the cells were centrifuged as described above, rinsed with flow buffer, and centrifuged once again as described above. The wash and centrifugation steps were repeated a total of three times. After the third wash, the cells were resuspended in flow buffer and a 
biotin-conjugated rabbit antirat polyclonal antibody (Zymed Laboratories, South San Francisco, CA, USA) was added to the cell suspension at a $1 / 500$ dilution. The cells then were incubated at $4{ }^{\circ} \mathrm{C}$ for $30 \mathrm{~min}$ with gentle rocking and subsequently washed exactly as described above. Upon completion of the wash steps, the cells were resuspended in flow buffer, streptavidin-conjugated phycoerythrin was added to the cell suspension at a 1/200 dilution, and the cells were incubated at $4^{\circ} \mathrm{C}$ in the dark for $20 \mathrm{~min}$ with gentle rocking. Following this incubation, cells were centrifuged as described above, resuspended in PBS $+0.05 \%$ sodium azide and recentrifuged. Resuspension of the cells and centrifugation was repeated a total of three times. After the final wash and centrifugation step, the cells were resuspended at a density of $5 \times 10^{6}$ cells $/ \mathrm{mL}$ in PBS $+0.05 \%$ sodium azide. Propidium iodide was added to the cells at a final concentration of $2.5 \mu \mathrm{g} / \mathrm{mL}$ and following $5 \mathrm{~min}$ incubation, the cells were transported to the University of Michigan Flow Cytometry Core. Viable cells that were surface-positive for mAb299 were sterile sorted by the Flow Cytometry Core. To identify viable, mAb299 surface-positive cells, the stable transfectants were compared against non-transfected HEK293T cells that had been mAb299 stained side-by-side with the stable line. Approximately $37 \%$ of the cells analyzed were identified as viable, mAb299positive cells.

The mAb299-positive cells were seeded in a culture flask in DMEM, $10 \%$ fetal bovine serum, antibiotic/antimycotic solution and selection drugs as described above and allowed to propagate to near confluence. Subsequent passages (passages 1-10) of these cells were used for all experiments in this report. These cells were designated as mma4b2 (Mus musculus $\alpha 4 \beta 2$ ).

\section{$\left[{ }^{3} \mathrm{H}\right]$-epibatidine binding}

mm $\alpha 4 \beta 2$ cells were seeded at a density of $5 \times 10^{6}$ cells $/ 100 \mathrm{~mm}$ dish. Approximately $72 \mathrm{~h}$ after plating, the cells were scraped from the dishes and membrane fractions were prepared as previously described (Marks et al. 1998), with the exception that a $15 \mathrm{~min}$ incubation at $37^{\circ} \mathrm{C}$ with $50 \mu \mathrm{g} / \mathrm{mL}$ DNAse was performed prior to the first centrifugation. The binding of $\left[{ }^{3} \mathrm{H}\right]$-epibatidine to the membrane fractions was performed in a $250 \mu \mathrm{L}$ reaction that included KRH buffer (118 mM NaCl, $4.8 \mathrm{~mm} \mathrm{KCl,} 2.5 \mathrm{~mm} \mathrm{CaCl}_{2}$, $1.2 \mathrm{mM} \mathrm{Mg}_{2} \mathrm{SO}_{4}$ and $20 \mathrm{~mm}$ HEPES $\mathrm{pH} 7.5$ ) and varying concentrations of $\left[{ }^{3} \mathrm{H}\right]$-epibatidine. Non-specific binding was determined by the inclusion of $10 \mu \mathrm{M}$ nicotine in the reaction. The binding reaction was terminated by filtration of the protein onto glass fiber filters that had been treated with $0.5 \%$ polyethylenimine in KRH buffer. Filtration was performed using a Tomtec Mach II cell harvester (Tomtec, Hamden, CT, USA). After filtration, the filters were washed four times with ice-cold buffer. The filters were collected and placed in scintillation vials. Following the addition of $3 \mathrm{~mL}$ scintillation fluid, the radioactivity was measured using a liquid scintillation counter (Beckman Coulter, Fullerton, CA, USA). Preliminary experiments were performed to determine the amount of cell membrane homogenate that would provide detectable binding without ligand depletion at low ligand concentrations. Ligand depletion was defined as c.p.m. of membrane-bound $\left[{ }^{3} \mathrm{H}\right]$-epibatidine/c.p.m. of total $\left[{ }^{3} \mathrm{H}\right]$-epibatidine $>25 \%$. Subsequent ligand binding was performed with an amount of homogenate that did not produce ligand depletion. Homogenate protein levels were determined by the method of Lowry (Lowry et al. 1951).

\section{Electrophysiological recording from mm $\alpha 4 \beta 2$ cells}

mm $\alpha 4 \beta 2$ cells were maintained in a humidified $5 \% \mathrm{CO}_{2}$ environment at $37^{\circ} \mathrm{C}$ in DMEM supplemented with $10 \%$ fetal bovine serum and antibiotics (100 U/mL penicillin, $100 \mu \mathrm{g} / \mathrm{mL}$ streptomycin). Between 24 and $48 \mathrm{~h}$ prior to recording, the cells were plated at a density of $3 \times 10^{5}$ cells $/ 60 \mathrm{~mm}$ dish and maintained in a humidified $5 \% \mathrm{CO}_{2}$ environment at $30^{\circ} \mathrm{C}$. For whole-cell recording, the external solution consisted of $140 \mathrm{~mm} \mathrm{NaCl}, 5 \mathrm{~mm} \mathrm{KCl}, 1 \mathrm{~mm}$ $\mathrm{MgCl}_{2}, 2 \mathrm{~mm} \mathrm{CaCl}_{2}, 10 \mathrm{~mm}$ glucose, $10 \mathrm{~mm}$ HEPES, pH 7.3. Recording electrodes were filled with an internal solution of $140 \mathrm{~mm}$ $\mathrm{CsCl}, 4 \mathrm{~mm} \mathrm{NaCl}, 4 \mathrm{~mm} \mathrm{MgCl}_{2}, 0.5 \mathrm{~mm} \mathrm{CaCl}_{2}, 5 \mathrm{~mm}$ EGTA, $10 \mathrm{~mm}$ HEPES pH 7.3, with $4 \mathrm{~mm}$ ATP added on the day of recording. nAchR receptor currents were recorded using a lifted whole-cell patch-clamp technique. Agonist was applied to cells using a modified SF-77B Perfusion Fast-Step application system (Warner Instrument Corp., Hamden, CT, USA). The application system provided for simultaneous flow of all solutions to which the cells were exposed through three parallel glass square barrels. All step protocols began with a cell positioned in the flow of external bath solution from which the multibarrelled array was repositioned such that the unmoved cell and electrode were now exposed to acetylcholine (Ach). All cells were voltage clamped at $-50 \mathrm{mV}$ during recordings. Currents were recorded using a 200B amplifier (Axon Instruments, Union City, CA, USA). All experiments were performed at room temperature $\left(22^{\circ} \mathrm{C}\right)$. Whole cell currents were analyzed using the programs PCLAMP 9.0 and PRISM (GraphPad, San Diego, CA). Whole-cell current amplitudes were obtained by measuring the peak current evoked during the application of drug. For Ach and tetramethylammonium chloride (TMA) concentrationresponse curves, the data were normalized to a percent of the maximum current elicited by saturating agonist concentrations for each cell. For methyllycaconitine (MLA) inhibition curves, MLA was applied to the cells for $1 \mathrm{~s}$ prior to the application of a solution containing $10 \mu \mathrm{M}$ nicotine and the pre-application concentration of MLA. Normalized concentrationresponse data were curve fitted using the sum of two Michaelis-Menten equations.

\section{Aequorin intracellular calcium measurement assay}

\section{Cell preparation}

mm $\alpha 4 \beta 2$ cells were seeded onto six-well plates $\left(1 \times 10^{6}\right.$ cells/well $)$ or $100 \mathrm{~mm}$ dishes $\left(5 \times 10^{6}\right.$ cells/dish $)$ and the following day transfected with the plasmid pcDNA into which a human codonoptimized aequorin cDNA had been cloned (Vernon and Printen 2002). Transfection was performed using the LipofectAmine Plus Reagent as recommended by the manufacturer (Invitrogen). Approximately $48-72 \mathrm{~h}$ following transfection, culture media was replaced with DMEM $+0.1 \%$ fetal bovine serum and $2.5 \mu \mathrm{M}$ coelenterizine-hcp (Molecular Probes, Eugene, OR, USA) and the cells were incubated for $3-4 \mathrm{~h}$ at $37^{\circ} \mathrm{C}$ in a humidified $5 \% \mathrm{CO}_{2}$ incubator. Following the coelenterizine incubation, cells were gently aspirated from the culture dishes and transferred to either $2 \mathrm{~mL}$ (sixwell plates) or $15 \mathrm{~mL}$ (100 mm dishes) centrifuge tubes. An equal volume of Hank's balanced salt solution supplemented with $100 \mathrm{~mm}$ calcium chloride was added and the cells were incubated for 5-10 min at room temperature. This step eliminated an artifactual injection peak presumably resulting from entry of calcium into non-viable permeable cells. The cells were then pelleted by centrifugation at $4{ }^{\circ} \mathrm{C}$ for $5 \mathrm{~min}$ at $800 \mathrm{~g}$, the supernatant was 
discarded, and the cells were resuspended in $1 \times$ assay buffer (130 mm NaCl, $5.4 \mathrm{~mm} \mathrm{KCl,} 10 \mathrm{~mm} \mathrm{CaCl}_{2}, 5 \mathrm{~mm}$ glucose, $25 \mathrm{~mm}$ HEPES, pH 7.5) and again pelleted by centrifugation. Subsequently, the cells were resuspended in fresh $1 \times$ assay buffer $(1 \mathrm{~mL} /$ well of a six-well plate or $6 \mathrm{~mL} / 100 \mathrm{~mm}$ dish) and incubated for $1-2 \mathrm{~h}$ at $4{ }^{\circ} \mathrm{C}$ prior to initiating the assay.

\section{Aequorin assay}

For agonist concentration-response curves, $50 \mu \mathrm{L}$ of each agonist concentration (in assay buffer) was added to each well of a 96-well opaque plate which was placed in a Beckman-Coulter LD400 luminometer. mm $\alpha 4 \beta 2$ cells were placed in a $7 \mathrm{~mL}$ scintillation vial connected to a luminometer injector line and gently mixed continuously with a stir bar. For Ach stimulations, the cells were incubated with $1 \mu \mathrm{M}$ atropine for $10-15 \mathrm{~min}$ at room temperature prior to initiating the assay. The assay was initiated by injection of $50 \mu \mathrm{L}$ of cells into each well of the agonist-containing plate. Agonist-stimulated luminescence was recorded at $0.15-0.2 \mathrm{~s}$ intervals for 15-20 s immediately following the addition of cells to each well. Each agonist concentration was measured in duplicate per aequorin transfection. Once the concentration-response recordings were complete for an entire 96-well plate, remaining aequorin luminescence was determined by injecting $100 \mu \mathrm{L}$ of a solution containing $0.1 \%$ Triton $\mathrm{X}-100$ and $100 \mathrm{~mm} \mathrm{CaCl}_{2}$ into each well and recording luminescence for $5 \mathrm{~s}$ at $0.1 \mathrm{~s}$ intervals. In order to control for differences in cell number per well and variation in the transfection efficiency of aequorin, agonist-stimulated luminescence was normalized by dividing the maximal peak value for the agoniststimulated luminescence $(L)$ by the total peak luminescence value $\left(L_{\max }\right)$ (maximal peak agonist-stimulated luminescence + maximal peak luminescence resulting from cell lysis in the presence of high calcium). All data, except raw data traces, are presented as the percent of total possible calcium-stimulated luminescence $\left(L / L_{\max }\right)$.

For antagonist concentration response curves, $25 \mu \mathrm{L}$ of mm $\alpha 4 \beta 2$ cells was added to each well of an opaque 96-well plate along with $25 \mu \mathrm{L}$ of the appropriate antagonist. The cells and antagonists were mixed and incubated for $10 \mathrm{~min}$ at room temperature. Following the $10 \mathrm{~min}$ incubation, $50 \mu \mathrm{L}$ of $10 \mu \mathrm{M}$ nicotine was injected onto the cells and luminescence was recorded at $0.2 \mathrm{~s}$ intervals for $20 \mathrm{~s}$. Marks et al. (1999) used a concentration of $10 \mu \mathrm{M}$ nicotine to evaluate antagonists $\mathrm{IC}_{50}$ values for a 'dihydro- $\beta$-ethroidine sensitive' $\alpha 4 \beta 2$ nAchR subtype present in mouse brain synaptosomes. Therefore, $10 \mu \mathrm{M}$ nicotine was used for the antagonist experiments with the mm $\alpha 4 \beta 2$ cells so that a comparison of the $\mathrm{IC}_{50}$ values could be made between the mm $\alpha 4 \beta 2$ cells and 'dihydro- $\beta$-ethroidine sensitive' $\alpha 4 \beta 2$ nAchRs present in mouse brain synaptosomes. After agonist incubation, total luminescence per well was recorded by injection of $100 \mu \mathrm{L}$ of $0.1 \%$ Triton $\mathrm{X}-100$ and $100 \mathrm{mM} \mathrm{CaCl}_{2}$ and recording luminescence for $5 \mathrm{~s}$ at $0.1 \mathrm{~s}$ intervals. All data are presented as $L / L_{\max }$ as described above.

Experiments with the voltage-sensitive calcium channel inhibitor $\mathrm{CdCl}_{2}(100 \mu \mathrm{M})$, and the inhibitors of intracellular calcium release, ryanodine $(30 \mu \mathrm{M})$ and xestospongin $\mathrm{C}(10 \mu \mathrm{M})$, were performed exactly as described for the antagonist experiments with the exceptions that the cells were incubated with the compounds for 30 min prior to agonist application and $1 \mu \mathrm{M}$ epibatidine was used as the agonist rather than $10 \mu \mathrm{M}$ nicotine. The concentration used for each inhibitor was based on data from others (Gafni et al. 1997;
Gueorguiev et al. 2000; Sharma and Vijayaraghavan 2001; Shoop et al. 2001; Dajas-Bailador et al. 2002).

\section{Data analysis}

Whole cell recording data were fitted to a two-site model using the sum of two Michaelis-Menten equations. Concentration-response curves for the aequorin assay were fitted to a four parameter logistic equation using PRISM 3.0 software. All data are represented as mean \pm S.E.M.

\section{Results}

\section{Generation of a cell line that expresses mouse $\alpha 4 \beta 2$ nicotinic receptors}

Plasmids carrying the cDNAs for the mouse nAchR subunits $\alpha 4$ and $\beta 2$ were transfected into HEK293T cells as described above. Following several weeks of growth in media supplemented with zeocin and hygromycin to select for cells that had stably integrated both plasmids, the cells were pooled and viable cells that were surface positive for the $\alpha 4$ subunit were immuno-isolated with the $\alpha 4$ subunit-specific antibody mAb299 (Whiting and Lindstrom 1988) by fluorescenceactivated cell sorting. Approximately $37 \%$ of the viable cells were selected as mAb299 immunopositive. These immunopositive cells, hereafter referred to as mma4 $\beta 2$, were propagated for experimental procedures. All experiments described in this report utilized the mm $\alpha 4 \beta 2$ cells between generations 2 and 10 .

\section{Ligand binding of mma4 42 cells}

To verify the expression of $\alpha 4 \beta 2$ nAchRs in the mm $\alpha 4 \beta 2$ cells, saturation binding with $\left[{ }^{3} \mathrm{H}\right]$-epibatidine was performed (Fig. 1). Results of the ligand binding indicated that the cells expressed $\alpha 4 \beta 2 \mathrm{nAchRs}$ with a $K_{\mathrm{D}}$ value for $\left[{ }^{3} \mathrm{H}\right]$-epibatidine

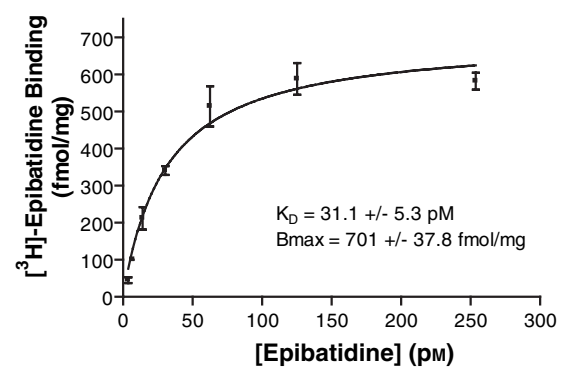

Fig. 1 Saturation binding of $\left[{ }^{3} \mathrm{H}\right]$-epibatidine to $\mathrm{mm} \alpha 4 \beta 2$ cell membrane fractions. Particulate fractions prepared from mma4 32 cells were incubated with $\left[{ }^{3} \mathrm{H}\right]$-epibatidine concentrations ranging between 3.8 and $500 \mathrm{pm}$. The binding of $\left[{ }^{3} \mathrm{H}\right]$-epibatidine to the particulate fractions was measured under conditions that minimized ligand depletion as described in Materials and methods. The $K_{\mathrm{D}}$ value for the receptors expressed in the $m m \alpha 4 \beta 2$ receptors was calculated to be $31.1 \pm 5.3 \mathrm{pm}$. The $B_{\max }$ value for the $\mathrm{mm} \alpha 4 \beta 2$ cells was $701 \pm 37.8$ $\mathrm{fmol} / \mathrm{mg}$ protein. Data represent the mean \pm SEM of three separate membrane preparations of the mm $\alpha 4 \beta 2$ cells. 
of $31.1 \pm 5.3 \mathrm{pm}$ and a $B_{\max }$ of $701 \pm 37.8 \mathrm{fmol} / \mathrm{mg}$ protein. The $K_{\mathrm{D}}$ value is consistent with the $K_{\mathrm{D}}$ for endogenous (Marks et al. 1998; Shafaee et al. 1999; Truong et al. 2001) and heterologously expressed $\alpha 4 \beta 2 \mathrm{nAchRs}$ (Shafaee et al. 1999; Chavez-Noriega et al. 2000; Truong et al. 2001; Eaton et al. 2003). The $B_{\max }$ value is similar to that reported for other stable cell lines expressing heterologous $\alpha 4 \beta 2 \mathrm{nAchRs}$ (Chavez-Noriega et al. 2000; Michelmore et al. 2002; Eaton et al. 2003).

\section{mm $\alpha 4 \beta 2$ cells express functional $\alpha 4 \beta 2$ nAchRs}

Whole-cell patch-clamp recording established that the mm $\alpha 4 \beta 2$ cells express functional $\alpha 4 \beta 2$ nAchRs. Figure 2 shows the concentration-response of the mm $\alpha 4 \beta 2$ cells to Ach. Curve fitting indicated that the Ach response curve was consistent with a two-component response with the lowaffinity response exhibiting an $\mathrm{EC}_{50}$ of $179 \pm 22 \mu \mathrm{M}$, and the high-affinity component possessing an $\mathrm{EC}_{50}$ value of $3.36 \pm 2.25 \mu \mathrm{M}$. The low-affinity component was responsible for $\sim 90 \%$ of the total response. The high proportion of the low-affinity response relative to the high-affinity response is consistent with other reports on the stable expression of $\alpha 4 \beta 2$ nAchRs in HEK cells (Buisson and Bertrand 2001; Nelson et al. 2003).

\section{Agonist-stimulated increase in intracellular calcium: requirement for extracellular calcium}

In order to further characterize the function of the mm $\alpha 4 \beta 2$ cell line, agonist-stimulated changes in intracellular calcium were determined using an aequorin-based luminescence assay (Brini et al. 1995; Vernon and Printen 2002). Several studies have demonstrated that the measurement of nicotinic receptor-mediated changes in intracellular calcium is dependent upon the concentration of extracellular calcium (Ragozzino et al. 1998; Xiao et al. 1998; Chavez-Noriega et al. 2000; Pacheco et al. 2001; Michelmore et al. 2002). Therefore, the extracellular calcium requirement for nicotinic agonist-stimulated changes in intracellular calcium in the mm $\alpha 4 \beta 2$ cell line was addressed by stimulating aequorintransfected mm $\alpha 4 \beta 2$ cells with $1 \mu \mathrm{M}$ epibatidine in the presence of concentrations of extracellular calcium ranging from nominally 0 to $10 \mathrm{~mm}$. Figure 3 shows the raw data traces of $1 \mu \mathrm{M}$ epibatidine-stimulated luminescence over a $15 \mathrm{~s}$ recording period. Consistent with previous reports, increasing the concentration of extracellular calcium resulted in an increase in the response to the $1 \mu \mathrm{M}$ epibatidine stimulation. Consequently, all experiments described below were performed in the presence of $10 \mathrm{~mm}$ calcium, the highest concentration of extracellular calcium tested.

\section{Pharmacological characterization of agonist-induced increases in intracellular calcium in mm $\alpha 4 \beta 2$ cells} Eight nAchR agonists were tested for their potency and efficacy in stimulating an increase in intracellular calcium (a)
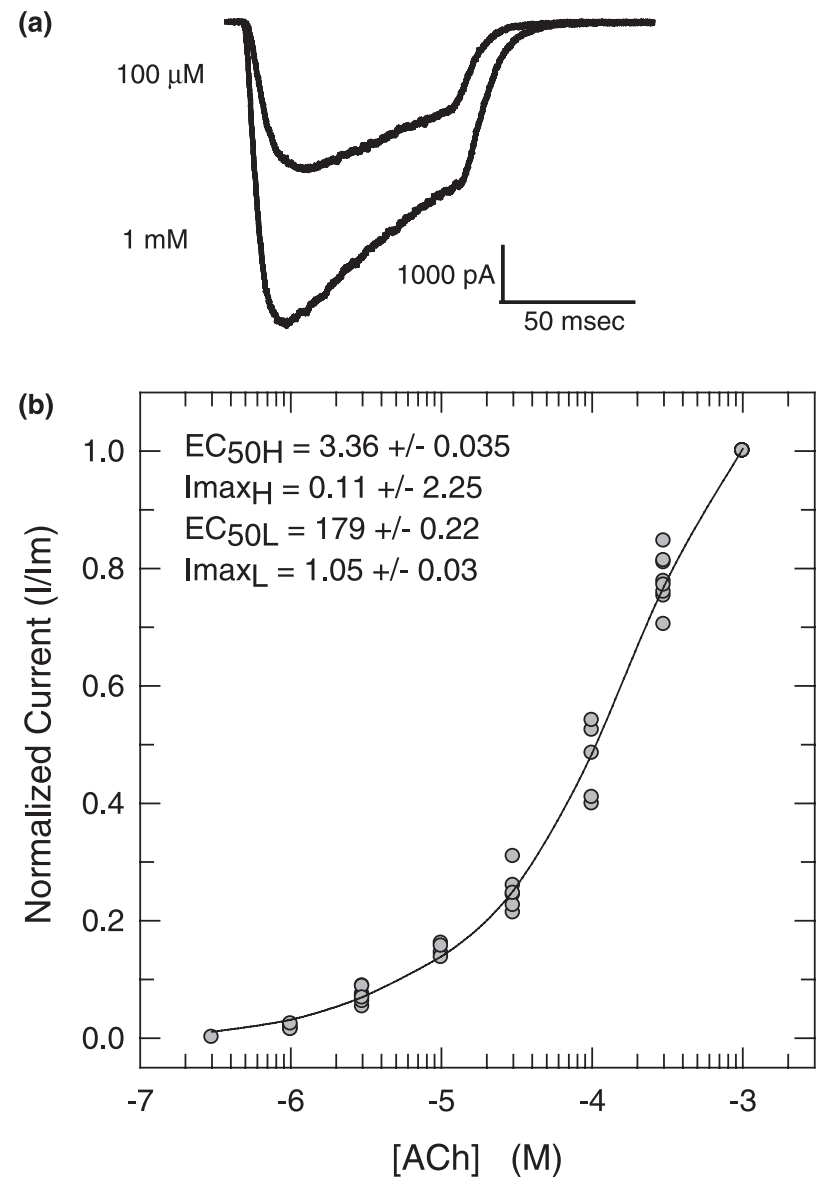

Fig. 2 Whole-cell patch-clamp Ach concentration response curve for the $m m \alpha 4 \beta 2$ cell line. The response of the $m m \alpha 4 \beta 2$ cells to Ach was measured using the lifted whole-cell patch-clamp method as described in Materials and methods. (a) Representative whole-cell currents from $\mathrm{mm} \alpha 4 \beta 2$ cells. Ach was applied for $80-200 \mathrm{~ms}$ voltage clamped at $-50 \mathrm{mV}$. (b) The concentration-response relationship was obtained by normalizing the peak response for each concentration of Ach to the maximal current response for each cell. (a) Data points for the concentration-response curve represent the mean \pm SEM of between four and eight separate measurements per Ach concentration. Data were fitted using the sum of two Michaelis-Menten equations. $\mathrm{EC}_{50}$ values for the low- $\left(\mathrm{EC}_{5 \mathrm{OL}}\right)$ and high-affinity $\left(\mathrm{EC}_{5 \mathrm{OH}}\right)$ components of the Ach response curve were estimated to be $179 \pm 22$ and $3.36 \pm 2.25 \mu \mathrm{m}$, respectively. Peak current for the low- $\left(I_{\operatorname{maxL}}\right)$ and high-affinity $\left(I_{\operatorname{maxH}}\right)$ components were estimated to be $1.05 \pm 0.03$ and $0.11 \pm 0.035$, respectively.

concentrations. Figure 4(a) shows the raw data traces of aequorin luminescence following stimulation with epibatidine concentrations ranging from $30 \mathrm{~nm}$ to $0.3 \mu \mathrm{M}$. As the epibatidine concentration was increased, the luminescence peak increased and became more distinct. The time to peak luminescence also decreased as the concentration of agonist increased. This concentration-dependent temporal shift in the aequorin peak response is a common feature of the aequorin-based assay. For example, Ungrin et al. 
Extracellular Calcium

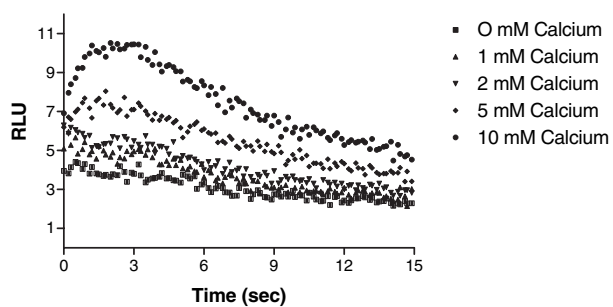

Fig. 3 Effect of extracellular calcium on epibatidine-stimulated changes in intracellular calcium in mm $\alpha 4 \beta 2$ cells. mm $\alpha 4 \beta 2$ cells were transfected with the luminescent calcium indicator protein aequorin and $48 \mathrm{~h}$ later loaded with the aequorin coenzyme coelenterizine-hcp as described in Materials and methods. Epibatidine $(1 \mu \mathrm{m})$ stimulated changes in intracellular calcium in the aequorin/coelenterizine-hcploaded mm $\alpha 4 \beta 2$ cells were subsequently determined in the presence of extracellular calcium ranging from 0 (nominal) to $10 \mathrm{~mm}$. Immediately following the injection of epibatidine onto the cells, luminescence $(\mathrm{RLU}=$ relative luminescence units) was measured at $0.15 \mathrm{~s}$ intervals for $15 \mathrm{~s}$ in a 96-well plate luminometer as described in Materials and methods. Data shown are representative traces from a single experiment.

(1999) described this temporal shift in response to increasing concentrations of prostanoids.

Concentration-response curves for epibatidine, as well as Ach, A85380, cytisine, dimethylphenylpiperazinium iodide (DMPP), methylcarbachol, nicotine and TMA are shown in Fig. 4(b). Because electrophysiological data indicated that $90 \%$ of the Ach response was due to a single component, data were fitted assuming single population kinetics. Of the agonists tested, epibatidine exhibited the lowest $\mathrm{EC}_{50}$ value $(0.033 \pm 0.001 \mu \mathrm{M})$ and Ach the highest $(66.3 \pm 2.23 \mu \mathrm{M})$ (Table 1). The rank order of $\mathrm{EC}_{50}$ values for the $\alpha 4 \beta 2$ mediated increase in intracellular calcium levels was epibatidine $<$ A85380 $<$ DMPP $=$ nicotine $<$ MCC $<$ TMA $<$ Ach. An $\mathrm{EC}_{50}$ value was not calculated for cytisine because the response to this drug did not fit a sigmoidal concentration-response curve. Of the agonists tested, Ach was the most efficacious in stimulating an increase in intracellular calcium, whereas cytisine was the least efficacious. The rank order of efficacy of the agonists was Ach $>$ epibatidine $=$ MCC $=$ TMA > A85380 > nicotine > DMPP > cytisine (Table 1).

\section{Antagonist inhibition of nicotine-stimulated intracellular calcium in mm $\alpha 4 \beta 2$ cells}

The ability of the nAchR antagonists decamethonium (DEC), dihydro- $\beta$-erythroidine (DH $\beta E)$, hexamethonium (HEX), mecamylamine (MEC) and MLA to inhibit the increase in intracellular calcium in response to $10 \mu \mathrm{M}$ nicotine was assessed in the mm $\alpha 4 \beta 2$ cells. Raw data traces of the effect of increasing concentrations of $\mathrm{DH} \beta \mathrm{E}$ on the nicotine-stimulated increase in intracellular calcium
Raw Data Trace
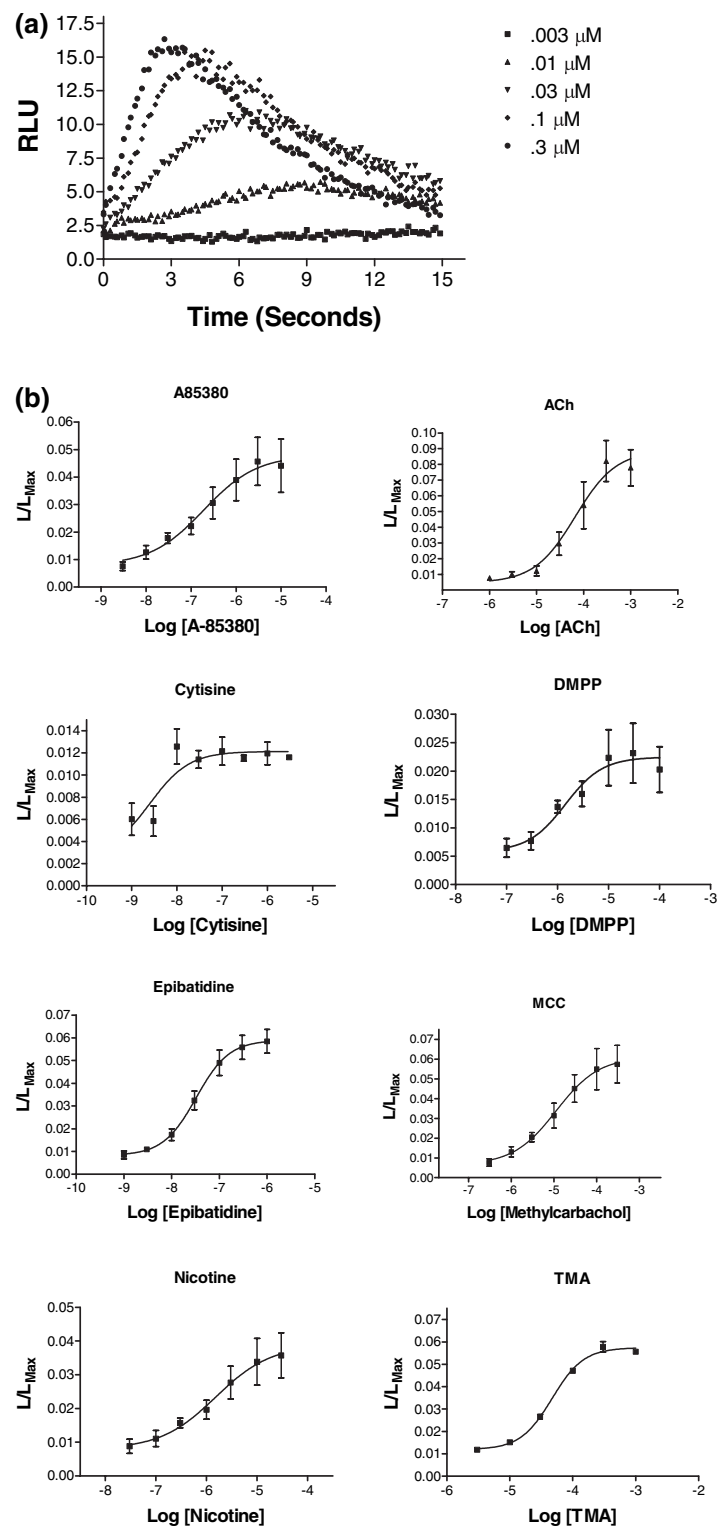

Fig. 4 Concentration-response curves for agonist induced changes in $\mathrm{mm} \alpha 4 \beta 2$ cell intracellular calcium. (a) Raw data trace of concentrationdependent changes in epibatidine (3-300 nM) stimulated luminescence in aeqourin/coelenterizine-hcp-loaded mma4ß2 cells. (RLU = relative luminescence units). Immediately upon addition of epibatidine to the aeqourin/coelenterizine-hcp-loaded mm $\alpha 4 \beta 2$ cells, luminescence was measured at $0.15 \mathrm{~s}$ intervals for $15 \mathrm{~s}$. (b) Concentrationresponse curves for agonist-induced changes in intracellular calcium. Data are represented as the ratio of agonist-induced peak aequorin luminescence $(L)$ divided by the sum of the possible aequorin luminescence $\left(L_{\max }\right.$; peak agonist induced luminescence + peak luminescence following cell lysis in the presence of $50 \mathrm{~mm}$ calcium). Data shown represent mean \pm SEM of between three and eight independent aequorin transfections per agonist). Data were fitted to a fourparameter logistic equation assuming a single site. $\mathrm{EC}_{50}$ values and maximal responses for each agonist are provided in Table 1. 
Table $1 \mathrm{EC}_{50}$ values $(\mu \mathrm{M})$ and maximal responses for mm $\alpha 3 \beta 2$ cells

\begin{tabular}{|c|c|c|c|c|c|c|c|c|}
\hline \multirow[b]{2}{*}{ Agonist } & \multirow{2}{*}{$\begin{array}{l}\mathrm{mm} \alpha 4 \beta 2 \\
\mathrm{EC}_{50}\end{array}$} & \multirow[b]{2}{*}{$R_{\max }$} & \multicolumn{2}{|c|}{$\begin{array}{l}\text { DHßE Sensitive } \\
\text { Marks et al. (1999) }\end{array}$} & \multicolumn{2}{|c|}{$\begin{array}{l}\text { DHßE Resistant } \\
\text { Marks et al. (1999) }\end{array}$} & \multirow{2}{*}{$\begin{array}{l}\text { Gopalakrishnan } \\
\text { et al. (1996) } \\
\text { EC }_{50}\end{array}$} & \multirow{2}{*}{$\begin{array}{l}\text { Chavez-Noriega } \\
\text { et al. }(2000) \\
\mathrm{EC}_{50}\end{array}$} \\
\hline & & & $\mathrm{EC}_{50}$ & $E_{\max }$ & $\mathrm{EC}_{50}$ & $E_{\max }$ & & \\
\hline A85380 & $0.19 \pm 0.04$ & $0.042 \pm 0.004$ & $0.018 \pm 0.006$ & $0.12 \pm 0.006$ & $40 \pm 8.5$ & $0.392 \pm 0.02$ & & \\
\hline Ach & $66.3 \pm 2.28$ & $0.087 \pm 0.009$ & $7.18 \pm 0.29$ & $0.149 \pm 0.011$ & $550 \pm 61$ & $0.158 \pm 0.005$ & $43.79 \pm 1.18$ & 100 \\
\hline Cytisine & - & $0.012 \pm 0.0006$ & $0.013 \pm 0.011$ & $0.017 \pm 0.003$ & $150 \pm 60$ & $0.068 \pm 0.007$ & & \\
\hline DMPP & $1.43 \pm 0.46$ & $0.022 \pm 0.002$ & $6.1 \pm 1.4$ & $0.102 \pm 0.005$ & $160 \pm 110$ & $0.043 \pm 0.008$ & $2.51 \pm 0.25$ & 6.7 \\
\hline Epibatidine & $0.033 \pm 0.001$ & $0.06 \pm 0.003$ & $0.057 \pm 0.016$ & $0.289 \pm 0.019$ & $2.2 \pm 0.3$ & $0.392 \pm 0.017$ & $0.017 \pm 0.002$ & 0.043 \\
\hline Methylcarbachol & $11.2 \pm 3.2$ & $0.057 \pm 0.005$ & $19.4 \pm 5.4$ & $0.192 \pm 0.012$ & $730 \pm 80$ & $0.218 \pm 0.007$ & & \\
\hline Nicotine & $1.53 \pm 0.43$ & $0.033 \pm 0.003$ & $1.39 \pm 0.42$ & $0.112 \pm 0.007$ & $130 \pm 20$ & $0.164 \pm 0.007$ & $3.99 \pm 0.11$ & 3.5 \\
\hline TMA & $46.9 \pm 0.36$ & $0.06 \pm 0.002$ & $185 \pm 32$ & $0.203 \pm 0.009$ & $890 \pm 720$ & $0.04 \pm 0.007$ & & \\
\hline
\end{tabular}

Values for the $\mathrm{mma}^{\beta 2}$ cells were calcuted by non-linear least squares curve fitting of the data shown in Fig. 4(B) using a four-parameter logistic equation. Values given are mean $\pm \mathrm{SEM}$. Mean values were calculated from a minimum of three separate aequorin transfections. $R_{\max }=\operatorname{maximal}$ response; $E_{\max }=$ maximal ${ }^{86} \mathrm{Rb}^{+}$efflux.

are shown in Fig. 5(a). Full concentration-response curves for the five antagonists are provided in Fig. 5(b). MLA was the most potent antagonist at inhibiting the nicotinestimulated increase in intracellular calcium $\left(\mathrm{IC}_{50}=\right.$ $31.6 \pm 1.2 \mathrm{nM})$, whereas HEX and DEC were the least potent $(1.96 \pm 0.13$ and $2.52 \pm 0.21 \mu \mathrm{M}$, respectively). The rank order of antagonist $\mathrm{IC}_{50}$ values was MLA < $\mathrm{DH} \beta \mathrm{E}=\mathrm{MEC}<\mathrm{HEX}=\mathrm{DEC}($ Table 2$)$.

\section{Mechanism of nicotine-stimulated increase in intracellular calcium}

Changes in intracellular calcium following nAchR stimulation can result from direct entry of calcium through the $\alpha 4 \beta 2$ $\mathrm{nAchR}$, as a result of activation of voltage-sensitive calcium channels or as a consequence of the release of intracellular stores of calcium. To identify the mechanism through which $\alpha 4 \beta 2 \mathrm{nAchR}$ stimulation increases intracellular calcium, cells
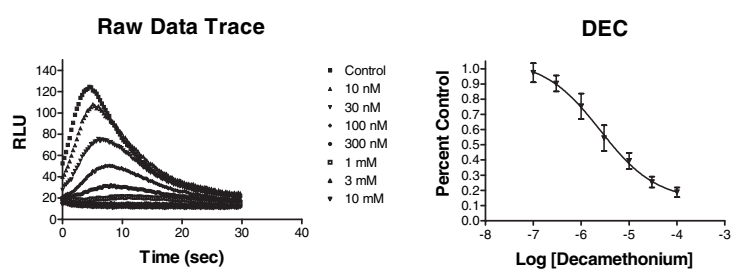

HEX

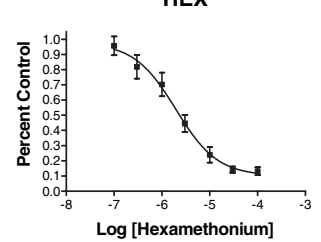

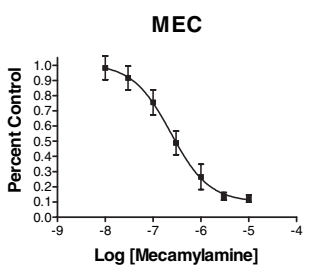

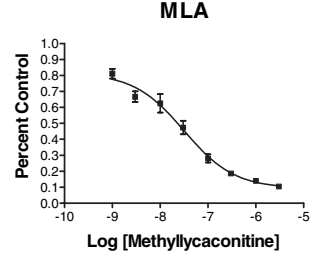

Fig. 5 Antagonist concentration-response curves for the inhibition of $\mathrm{mm} \alpha 4 \beta 2$ receptor function. The ability of the nicotinic antagonists $\mathrm{DEC}, \mathrm{DH} \beta E, \mathrm{HEX}, \mathrm{MEC}$ and MLA to inhibit nicotine $(10 \mu \mathrm{m})$ stimulated luminescence in aeqourin/coelenterizine-hcp-loaded mm $\alpha 4 \beta 2$ cells was evaluated. The upper left-hand panel shows a raw data trace of the concentration-dependent inhibition of nicotine-stimulated aequorin luminescence by $\mathrm{DH} \beta E$ (RLU = relative luminescence units) over a $30 \mathrm{~s}$ recording period. $\mathrm{mm} \alpha 4 \beta 2$ cells were incubated with each antagonist for 10-15 min prior to stimulation with $10 \mu \mathrm{m}$ nicotine. Immediately upon the addition of nicotine, luminescence was recorded at
$0.2 \mathrm{~s}$ intervals for $20 \mathrm{~s}$. Data were calculated as the ratio of agonist induced peak aequorin luminescence $(L)$ divided by the sum of the possible aequorin luminescence $\left(L_{\max }\right.$; peak agonist induced luminescence + peak luminescence following cell lysis in the presence of $50 \mathrm{~mm}$ calcium). Results presented represent the percent $L / L_{\text {max }}$ relative to $10 \mu \mathrm{m}$ nicotine stimulation in the absence of antagonist. Data shown represent the mean \pm SEM of between three and four independent aequorin transfections per antagonist). Data were fitted to a four-parameter logistic equation. $\mathrm{IC}_{50}$ values for each antagonist are provided in Table 2. 
Table $2 \quad I_{50}$ values $(\mu \mathrm{M})$ for $m m \alpha 4 \beta 2$ cells

\begin{tabular}{lll}
\hline Antagonist & $\mathrm{mm} \alpha 4 \beta 2$ & $\begin{array}{l}\text { Marks et al. (1999) } \\
\mathrm{DH} \beta \mathrm{E} \text { Sensitive }\end{array}$ \\
\hline Decamethonium & $2.52 \pm 0.21$ & $4.1 \pm 1.7$ \\
DH $\beta$ E & $0.17 \pm 0.03$ & $0.15 \pm 0.05$ \\
Hexamethonium & $1.96 \pm 0.13$ & $16.6 \pm 6.1$ \\
Mecamylamine & $0.24 \pm 0.013$ & $0.59 \pm 0.09$ \\
MLA & $0.03 \pm 0.0012$ & $0.20 \pm 0.06$
\end{tabular}

$I C_{50}$ values were calculated using by non-linear least squares curve fitting of the curves shown in Fig. 5. Values given are mean \pm SEM. Mean values were calculated from a minimum of four separate aequorin transfections.

were stimulated with $1 \mu \mathrm{m}$ epibatidine in the presence of either $100 \mu \mathrm{M} \mathrm{CdCl}_{2}, 30 \mu \mathrm{M}$ ryanodine or $10 \mu \mathrm{M}$ xestospongin $\mathrm{C}$ as described above (Fig. 6). Inclusion of the general high-voltage sensitive calcium channel inhibitor $\mathrm{CdCl}_{2}$ had no effect on the levels of epibatidine-stimulated intracellular calcium. In contrast, inhibition of ryanodine receptordependent intracellular calcium release by ryanodine or IP3-receptor-dependent intracellular calcium release by xestospongin $\mathrm{C}$ reduced epibatidine-stimulated intracellular calcium to $80 \pm 1.3$ and $85.4 \pm 3.0 \%$ of control, respectively. Inclusion of both ryanodine and xestospongin $\mathrm{C}$ led to a response that was $72.1 \pm 4.6 \%$ of the control response. Therefore, the nicotinic agonist-stimulated changes in intracellular calcium as measured with the aequorin-based assay

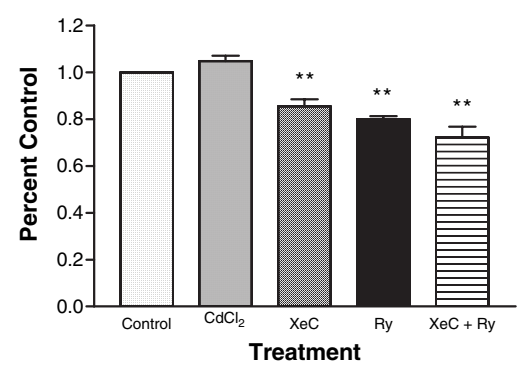

Fig. 6 Role of voltage-operated calcium channels and intracellular calcium stores in the epibatidine-evoked increase in intracellular calcium in mm $\alpha 4 \beta 2$ cells. Aequorin/coelenterizine-hcp-loaded mm $\alpha 4 \beta 2$ cells were stimulated with $1 \mu \mathrm{m}$ epibatidine after $30 \mathrm{~min}$ incubation with vehicle (control), $100 \mu \mathrm{M} \mathrm{CdCl}_{2}, 30 \mu \mathrm{m}$ ryanodine (Ry) and $10 \mu \mathrm{m}$ xestospongin $\mathrm{C}(\mathrm{XeC})$ or $30 \mu \mathrm{m}$ ryanodine $+10 \mu \mathrm{m}$ xestospongin $\mathrm{C}$ $(\mathrm{Ry}+\mathrm{XeC})$. Immediately upon injection of epibatidine onto the cells, luminescence was recorded at $0.2 \mathrm{~s}$ intervals for $20 \mathrm{~s}$. Data were calculated as the ratio of agonist-induced peak aequorin luminescence $(L)$ divided by the sum of the possible aequorin luminescence $\left(L_{\max }\right.$; peak agonist induced luminescence + peak luminescence following cell lysis in the presence of $50 \mathrm{~mm}$ calcium). Results presented represent the percent $L / L_{\max }$ relative to the epibatidine response in the presence of vehicle. Data shown represent the mean \pm SEM of between three and six independent aequorin transfections per drug treatment). Data were analyzed by means of one-way ANOVA. ${ }^{\star *} p<0.001$ relative to control response. appear to be predominantly due to entry of calcium through the receptor channel with a contribution of $\sim 28 \%$ from the release of calcium from intracellular stores.

\section{Discussion}

We report the functional characterization of a cell line that stably expresses a mouse $\alpha 4 \beta 2 \mathrm{nAchR}$. This is the first report of a stable heterologous expression system for the characterization of mouse $\alpha 4 \beta 2 \mathrm{nAchRs}$. Moreover, this is the first report where the aequorin-based luminescence assay was used to measure neuronal nAchR-mediated changes in intracellular calcium. The aequorin assay provides a new and relatively simple method to measure $\mathrm{nAchR}$ function in mammalian cell culture systems.

Consistent with previous reports (Buisson and Bertrand 2001; Nelson et al. 2003), stable expression of mouse $\alpha 4 \beta 2$ nAchRs in HEK293T cells leads to the expression of two receptor populations. The predominant subpopulation $(90 \%$ of the whole-cell patch-clamp response) of receptors exhibits an $\mathrm{EC}_{50}$ value for Ach of $179 \pm 22 \mu \mathrm{M}$ and the minor component has an $\mathrm{EC}_{50}$ value for Ach of $3.36 \pm 2.25 \mu \mathrm{M}$. Using HEK cells stably transfected with the human $\alpha 4$ and $\beta 2$ nAchR subunits, Nelson et al. (2003) recently demonstrated that the receptor population with high Ach affinity $\left(\mathrm{EC}_{50}=0.7 \pm 0.4 \mu \mathrm{M}\right)$ has a stoichiometry of $\alpha 4_{2} \beta 2_{3}$ and the low-affinity population $\left(\mathrm{EC}_{50}=74 \pm 6 \mu \mathrm{M}\right)$ represents $\alpha 4 \beta 2 \mathrm{nAchRs}$ with a stoichiometry of $\alpha 4_{3} \beta 2_{2}$. Therefore, the low Ach sensitivity of the predominant $\alpha 4 \beta 2 \mathrm{nAchR}$ in the mm $\alpha 4 \beta 2$ cells is consistent with an $\alpha 4 \beta 2 \mathrm{nAchR}$ that has a stoichiometry of $\alpha 4_{3} \beta 2_{2}$.

Comparison of the aequorin assay-determined $\mathrm{EC}_{50}$ values for the mm $\alpha 4 \beta 2$ line with those of human $\alpha 4 \beta 2 \mathrm{nAchRs}$ stably expressed in HEK cells indicates that the pharmacology of the mouse and human $\alpha 4 \beta 2 \mathrm{nAchR}$ are very similar (Table 1). The correlation between the $\mathrm{EC}_{50}$ values for the mouse and human $\alpha 4 \beta 2$ cell lines for the four common agonists tested between studies (Ach, epibatidine, DMPP and nicotine $)$ is $0.984(r, p<0.01$, slope $=1.02)$ when compared with human $\alpha 4 \beta 2$-mediated changes in intracellular calcium (Chavez-Noriega et al. 2000) and $0.973(r, p<0.05$, slope $=1.00)$ when compared with human $\alpha 4 \beta 2$-mediated ${ }^{86} \mathrm{Rb}^{+}$efflux (Gopalakrishnan et al. 1996). Also, the mm $\alpha 4 \beta 2$ cell line exhibited an $\mathrm{EC}_{50}$ value for Ach activation $(66.3 \pm 2.28 \mu \mathrm{M})$ that is quite similar to the $\mathrm{EC}_{50}$ value for Ach observed in a variety of independently derived human a4ß2 HEK stable cell lines $(43.79 \pm 1.18 \mu \mathrm{M}$, Gopalakrishnan et al. 1996; $100 \mu \mathrm{M}$, Chavez-Noriega et al. 2000; $74 \pm 6 \mu \mathrm{M}$, Nelson et al. 2003) and to the $\mathrm{EC}_{50}$ value for Ach in oocytes when equal amounts of $\alpha 4$ and $\beta 2$ cRNAs are injected (65.6 \pm 20.2 , Zwart and Vijverberg 1998).

When the pharmacology of the mm $\alpha 4 \beta 2$ cell line was compared with that of human $\alpha 4 \beta 2$ cells stably expressed in SH-EP cells (Eaton et al. 2003), no significant correlation 
was detected (adjusted $R^{2}=-0.18, p>0.5$ ). This lack of correlation is driven by the $\sim 35$-fold lower $\mathrm{EC}_{50}$ values for Ach and epibatidine in the SH-EP cells. The observation that $\alpha 4 \beta 2$ nAchRs in SH-EP cells exhibit an $\mathrm{EC}_{50}$ value for Ach in the $1 \mu \mathrm{M}$ range suggests that the receptor stoichiometry in this cell line may be $(\alpha 4)_{2}(\beta 2)_{3}$ (Zwart and Vijverberg 1998; Nelson et al. 2003; Zhou et al. 2003). However, there are other possible explanations for the differences in pharmacology of the $\alpha 4 \beta 2$ nAchRs expressed in the SH-EP cells relative to the HEK cells such as cell-type differences in lipid composition (Zanello et al. 1996) or cell-type specific receptor-protein interactions (Lin et al. 2002).

$\mathrm{A}^{86} \mathrm{Rb}^{+}$efflux assay has been utilized to demonstrate that there are two major pharmacologically distinct responses in mouse brain synaptosomes that require the nAchR $\alpha 4$ and $\beta 2$ subunits (Marks et al. 1999). The two $\alpha 4$ - and $\beta 2$-dependent components can be separated into a DH $\beta \mathrm{E}$-sensitive and a DH $\beta E-$ resistant component. A comparison of the pharmacological profile of the mma4 $\beta 2$ cells with that of agonistinduced ${ }^{86} \mathrm{Rb}^{+}$efflux from mouse brain synaptosomes indicates that the mm $\alpha 4 \beta 2$ cells exhibit an agonist pharmacology most similar to the DH $\beta E$-sensitive component (Fig. 7); the regression line for this comparison is essentially superimposed upon the line of identity $(r=0.875$, slope $=$ 1.00). In contrast, the regression line for the comparison between the $\mathrm{EC}_{50}$ values for the mm $\alpha 4 \beta 2$ cells and the DH $\beta E$-resistant response is distinct from the line of identity $(r=0.94$, slope $=0.71)$. Agonist efficacies are also most similar between the mm $\alpha 4 \beta 2$ cells and the DH $\beta E$-sensitive response (Table 1). For example, TMA, an agonist that exhibits high efficacy for the DH $\beta E$-sensitive component but very poor efficacy for the DH $\beta E$-resistant component, displays high efficacy for the $\alpha 4 \beta 2 \mathrm{nAchR}$ expressed in the mma4 32 cell line.

A comparison of antagonist inhibition profiles between the mm $\alpha 4 \beta 2$ cells and the mouse brain synaptosomal ${ }^{86} \mathrm{Rb}^{+}$ efflux DH $\beta E$-sensitive response demonstrated that the $\mathrm{IC}_{50}$ values for DH $\beta E, D E C$ and MEC in the mm $\alpha 4 \beta 2$ cells are

Fig. 7 Pharmacological comparison between mm $\alpha 4 \beta 2$ cells and nAchR-mediated ${ }^{86} \mathrm{Rb}^{+}$efflux from mouse brain synaptosomes. (a) Comparison of agonist $\mathrm{EC}_{50}$ values between $\mathrm{mm} \alpha 4 \beta 2$ cells and the $\mathrm{DH} \beta \mathrm{E}$-sensitive component of ${ }^{86} \mathrm{Rb}^{+}$efflux from mouse brain synaptosomes. The solid line represents regression line for two nAchRmediated responses. The dotted line with cross-hairs represents the line of identity. (b) Comparison of agonist $\mathrm{EC}_{50}$ values between $\mathrm{mm} \alpha 4 \beta 2$ cells and the $\mathrm{DH} \beta \mathrm{E}$-resistant component of ${ }^{86} \mathrm{Rb}^{+}$efflux from mouse brain synaptosomes. The solid line represents regression line for the two nAchR-mediated responses. The dotted line with crosshairs represents the line of identity. (c) Comparison of antagonist $I C_{50}$ values between mm $\alpha 4 \beta 2$ cells and the $\mathrm{DH} \beta \mathrm{E}$-sensitive component of ${ }^{86} \mathrm{Rb}^{+}$efflux from mouse brain synaptosomes. The solid line represents regression line for the two nAchR-mediated responses. The dotted line with cross-hairs represents the line of identity. ${ }^{*} p<0.05$; ${ }^{* *} p<0.01 ;{ }^{* * *} p<0.005$. consistent with the $\mathrm{IC}_{50}$ values for these antagonists for the DH $\beta E$-sensitive component (Table 2, Fig. 7). In contrast, the mm $\alpha 4 \beta 2$ cells exhibited $\mathrm{IC}_{50}$ values for HEX and MLA that are 7-8-fold lower than the $\mathrm{IC}_{50}$ values for these antagonists for the DH $\beta E$-sensitive component of $\mathrm{Rb}^{+}$efflux. No attempt was made to compare the $\mathrm{IC}_{50}$ values from the mm $\alpha 4 \beta 2$ cell line with those of the $\mathrm{DH} \beta \mathrm{E}-$-resistant component or the $\mathrm{IC}_{50}$
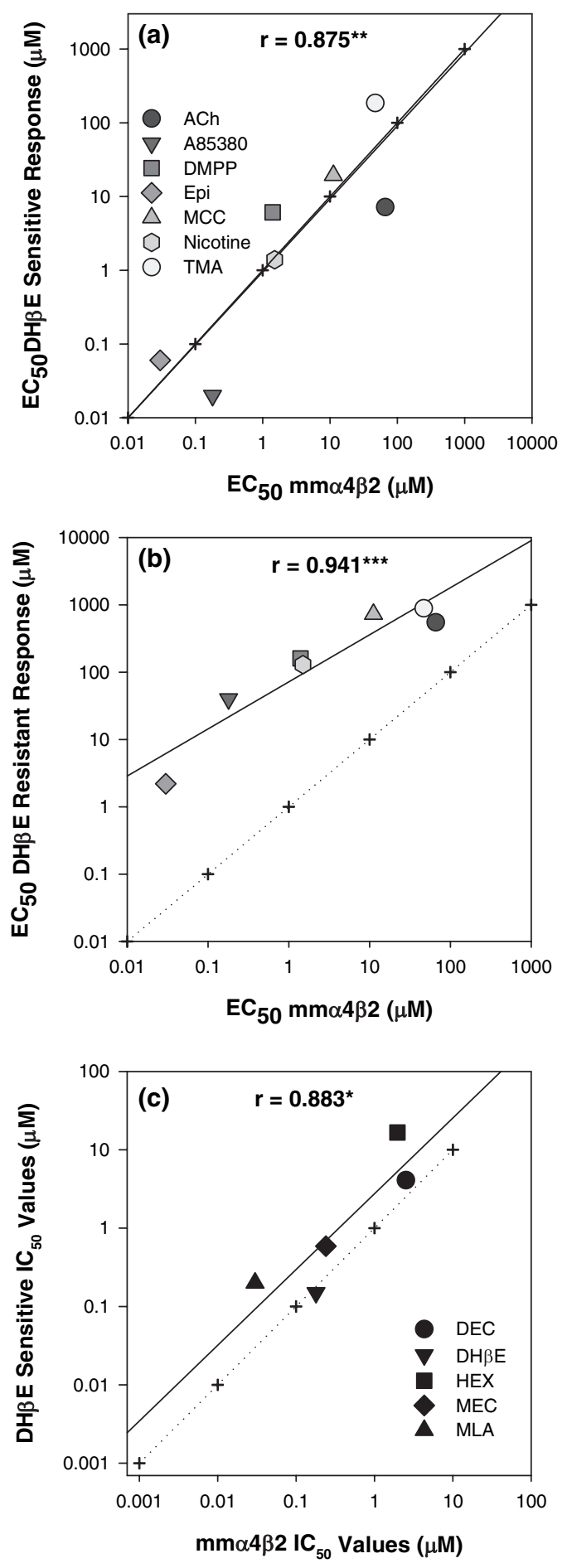
values of other stable lines because different agonists were used to evaluate the antagonists in the DHßE-resistant component and the other stable lines.

Owing to the similarities in their agonist pharmacologies and their similar sensitivity to the antagonist $\mathrm{DH} \beta \mathrm{E}$, it is tempting to speculate that the $\alpha 4 \beta 2$ nAchRs mediating nicotinic responses in the mm $\alpha 4 \beta 2$ cells possess the same stoichiometry and/or post-translational modifications as do the receptors that mediate the DH $\beta E$-sensitive component of ${ }^{86} \mathrm{Rb}^{+}$efflux. However, the agonist and antagonist pharmacologies of the DH $\beta E$-sensitive component of ${ }^{86} \mathrm{Rb}^{+}$efflux and the mma4 32 cells are not identical. Consequently, despite the considerable similarities in pharmacology

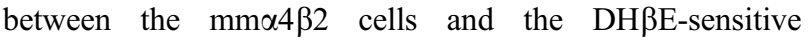
response, it is not clear whether a receptor with identical stoichiometry and/or post-translational modifications is responsible for both $\alpha 4 \beta 2$-mediated responses.

One potential explanation for the pharmacological differences between the mouse brain synaptosomes and mm $\alpha 4 \beta 2$ cells is the fact that the synaptosomes were prepared from a mouse strain that expresses an $\alpha 4$ subunit that has a threonine at amino acid position 529 , whereas the mm $\alpha 4 \beta 2$ cell line expresses a receptor with an alanine at this position. Previous studies have shown that this polymorphism influences receptor function (Dobelis et al. 2002; Kim et al. 2003). The development of a cell line that expresses an $\alpha 4 \beta 2 \mathrm{nAchR}$ with the threonine variant of the $\alpha 4$ subunit would be useful to address this issue.

One striking difference in the pharmacology of the mm $\alpha 4 \beta 2$ cell line relative to the reported pharmacology of other $\alpha 4 \beta 2 \mathrm{nAchRs}$ is the very low $\mathrm{IC}_{50}$ value of the mm $\alpha 4 \beta 2$ cell line for MLA. The $\mathrm{IC}_{50}$ value of $31 \pm 1.2 \mathrm{nM}$ for MLA inhibition of receptor function in the mma $4 \beta 2$ cells is not only lower than the $\mathrm{IC}_{50}$ value observed for this antagonist in inhibiting the DH $\beta E$-sensitive component of ${ }^{86} \mathrm{Rb}^{+}$efflux (Marks et al. 1999), it also is considerably lower than the reported low micromolar $\mathrm{IC}_{50}$ values for MLA inhibition of other heterologous $\alpha 4 \beta 2 \mathrm{nAchR}$ expression systems (Buisson et al. 1996; Eaton et al. 2003). MLA has been shown to inhibit $\alpha 7$-containing nAchRs with $\mathrm{IC}_{50}$ values in the high picomolar to low nanomolar range (Alkondon et al. 1992; Palma et al. 1996; Virginio et al. 2002; Zhou et al. 2003). Owing to the substantial differences in reported IC50 values for MLA inhibition of $\alpha 7 \mathrm{nAchRs}$ versus other $\mathrm{nAchR}$ subtypes, MLA is generally regarded as a highly selective antagonist for nAchRs comprised of the $\alpha 7$ subunit. However, in addition to the data reported here, others have reported that MLA can inhibit non- $\alpha 7$-mediated responses in the low nanomolar range. Clarke and Reuben (1996) demonstrated that nicotine-stimulated $\left[{ }^{3} \mathrm{H}\right]$-dopamine release from rat brain striatal synaptosomes can be inhibited by MLA with an $\mathrm{IC}_{50}$ value of 38 nm. Similarly, Grady et al. (1997) found that the transient phase of nicotine-stimulated dopamine release from mouse brain synaptosomes was inhibited by MLA with an
$\mathrm{IC}_{50}$ value of $36 \mathrm{~nm}$. Receptors containing the $\alpha 7$ subunit are not likely involved in $\left[{ }^{3} \mathrm{H}\right]$-dopamine release from either mouse or rat brain synaptosomes as the classic $\alpha 7$ antagonist $\alpha$-bungarotoxin does not inhibit nicotinic agonist-stimulated $\left[{ }^{3} \mathrm{H}\right]$-dopamine release from either species (Rapier et al. 1990; Grady et al. 1992) and nicotinic agonist-stimulated $\left[{ }^{3} \mathrm{H}\right]$-dopamine release does not differ between $\alpha 7$ subunit null mutant mice and their wild-type controls (Salminen et al. 2004). In contrast, Grady et al. (2002) have demonstrated that the $\beta 2$ subunit is an absolute requirement for nicotine-induced $\left[{ }^{3} \mathrm{H}\right]$-dopamine release and the $\alpha 4$ subunit is essential for $\sim 80 \%$ of nicotine-stimulated $\left[{ }^{3} \mathrm{H}\right]$-dopamine release (Salminen et al. 2004). Furthermore, Mogg et al. (2002) have shown that a presumed $\alpha 3 / \alpha 6 \beta 2 \beta 2 \mathrm{nAchR}$ in rat striatum is inhibited by low nanomolar concentrations of MLA. These data indicate that MLA can inhibit non- $\alpha 7$-mediated responses at low nanomolar concentrations in heterologous expression systems as well as in rodent brain synaptosomes and suggest that this antagonist may not be as selective in the low nanomolar range for $\alpha 7$-containing nAchRs as previously thought.

The inhibition of non- $\alpha 7$-mediated responses by low nanomolar concentrations of MLA was observed in neurotransmitter release and intracellular calcium-based assays. In contrast, the reported inhibition of $\alpha 4 \beta 2$ nAchRs by high nanomolar to low micromolar concentrations of MLA were determined by ion flux (Marks et al. 1999; Eaton et al. 2003) and electrophysiological (Buisson et al. 1996) assays. Therefore, the potency of MLA at inhibiting nAchR-mediated responses may be dependent upon the assay used to evaluate the drug. In support of this possibility, we have determined the $\mathrm{IC}_{50}$ value for MLA inhibition of mm $\alpha 4 \beta 2$ receptor function using whole-cell patch-clamp electrophysiology. Using this method, we observed an $\mathrm{IC}_{50}$ value for MLA of $0.43 \pm 1.2 \mu \mathrm{M}$ (data not shown). This $\mathrm{IC}_{50}$ value for MLA is more consistent with the $\mathrm{IC}_{50}$ values previously reported for MLA inhibition of $\alpha 4 \beta 2 \mathrm{nAchRs}$ when measured by ${ }^{86} \mathrm{Rb}^{+}$ efflux or electrophysiological methods (Buisson et al. 1996; Marks et al. 1999; Eaton et al. 2003).

Fitch et al. (2003) also found significant differences in the pharmacology of an $\alpha 3 \beta 4$ cell line when evaluated by different methods. This group observed that the nicotinic antagonist mecamylamine was equipotent at inhibiting receptor function in an intracellular calcium assay and an ${ }^{86} \mathrm{Rb}^{+}$efflux assay but $\sim 25$-fold less potent at inhibiting responses in the membrane potential assay. The agonist A85380 also was 6-fold less potent at stimulating responses in the intracellular calcium assay compared with the ${ }^{86} \mathrm{Rb}^{+}$efflux assay and 30 times less potent when compared with the membrane potential assay. Other substantial differences in agonist pharmacologies across methodologies were also reported by Fitch et al. (2003). Unfortunately, MLA was not evaluated in this study. Similarly, in the mm $\alpha 4 \beta 2$ cells, considerable differences 
in the potencies of $\mathrm{Ach}\left(\mathrm{EC}_{50}\right.$, aequorin: $66.3 \pm 2.2 \mu \mathrm{M}$; whole-cell recording: $179 \pm 22 \mu \mathrm{M}$ ), TMA ( $\mathrm{EC}_{50}$, aequorin: $46.9 \pm 0.36 \mu \mathrm{M}$; whole cell recording: $243 \pm 1.1 \mu \mathrm{M}$; data not shown) and MLA ( $\mathrm{IC}_{50}$, aequorin: $0.03 \pm 0.0012 \mu \mathrm{M}$; whole-cell recording: $0.43 \pm 1.2 \mu \mathrm{M}$ ) were observed when determined by aequorin and electrophysiological methods. Ach, TMA and MLA were the only compounds tested in the mm $\alpha 4 \beta 2$ cells by both methods. Regardless, these data and the data reported by Fitch et al. suggest that caution should be used when assigning the nAchR subtype specificity of a nicotinic compound based on the potency of the compound as determined by a single method of functional analysis.

The data reported here also established that the $\alpha 4 \beta 2$ nAchR-mediated increase in intracellular calcium in the $m m \alpha 4 \beta 2$ cells is due predominantly to direct entry of calcium through the receptor channel. Release of calcium from both ryanodine- and $\mathrm{IP}_{3}$-sensitive intracellular stores also appears to contribute to the increase in intracellular calcium. Dantroline, another inhibitor of ryanodine-sensitive calcium release, inhibited epibatidine-evoked changes in intracellular calcium to the same extent as ryanodine (data not shown) indicating that the effect of ryanodine on intracellular calcium release was not due to a non-specific effect of the drug. However, it cannot be entirely ruled out that the apparent blockade of $\mathrm{IP}_{3}$-sensitive calcium stores by xestospongin $\mathrm{C}$ is due to a non-specific effect of the drug such as blockade of the nAchR channel or other ion channel (Ozaki et al. 2002). There was no detectable contribution of high-voltage-sensitive calcium channels to the rise in intracellular calcium. However, HEK293T cells likely do not possess the full complement of voltage-sensitive calcium channels present in neurons. Therefore, these results must be interpreted with caution. Regardless, these data suggest that a $4 \beta 2$ nAchRs do not require the contribution of highvoltage-sensitive calcium channels in order to elicit a discernable rise in intracellular calcium. The lack of requirement for voltage-sensitive calcium channels for $\alpha 4 \beta 2$-mediated changes in intracellular calcium is consistent with other reports on heterologously expressed $\alpha 4 \beta 2 \mathrm{nAchRs}$ (Chavez-Noriega et al. 2000; Michelmore et al. 2002) and

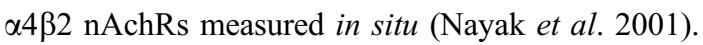

Previous studies have shown that the mechanism of nAchR-mediated changes in intracellular calcium levels is subtype specific (Gray et al. 1996; Tsuneki et al. 2000; Shoop et al. 2001; Dajas-Bailador et al. 2002). For example, several groups have reported that $\alpha 7$ subunit-containing nAchRs do not require the contribution of voltage-sensitive calcium channels in order to elicit agonist-induced changes in intracellular calcium (Gray et al. 1996; Tsuneki et al. 2000; Shoop et al. 2001; Dajas-Bailador et al. 2002). In contrast, changes in intracellular calcium resulting from the stimulation of some nAchRs that contain the $\alpha 3$ subunit (Shoop et al. 2001; Dajas-Bailador et al. 2002) and some
nAchRs that contain the $\beta 2$ subunit (Tsuneki et al. 2000) appear to require the activation of voltage-sensitive calcium channels. This suggests that the effect of nAchR activation on calcium-dependent cellular processes depends upon which particular subtype or subtypes are activated. Therefore, nicotinic agonist effects on such calcium-dependent cellular processes as signal transduction pathways, transcription factor expression and activation, synaptic plasticity and neuroprotection would depend upon which nAchR subtype is activated. Further studies to evaluate nAchR subtype-specific changes in intracellular calcium and the affected downstream signaling pathways should provide a better appreciation for the role of specific nAchR subtypes in brain function and disease.

\section{Acknowledgements}

The authors would like to thank Mr Brody Flanagin and Mr Paul Jenkins for their expert technical assistance. This work supported by DA-14369 from the National Institutes of Health (NIDA).

\section{References}

Alkondon M., Pereira E. F., Wonnacott S. and Albuquerque E. X. (1992) Blockade of nicotinic currents in hippocampal neurons defines methyllycaconitine as a potent and specific receptor antagonist. Mol. Pharmacol. 41, 802-808.

Alkondon M., Pereira E. F. and Albuquerque E. X. (1996) Mapping the location of functional nicotinic and gamma-aminobutyric acid A receptors on hippocampal neurons. J. Pharmacol. Exp. Ther. 279, 1491-1506.

Benwell M. E., Balfour D. J. and Anderson J. M. (1988) Evidence that tobacco smoking increases the density of $(-)-\left[{ }^{3} \mathrm{H}\right]$ nicotine binding sites in human brain. J. Neurochem. 50, 1243-1247.

Berridge M. J. (1998) Neuronal calcium signaling. Neuron 21, 13-26.

Bertrand D., Galzi J. L., Devillers-Thiery A., Bertrand S. and Changeux J. P. (1993) Mutations at two distinct sites within the channel domain M2 alter calcium permeability of neuronal alpha 7 nicotinic receptor. Proc. Natl Acad. Sci. USA 90, 6971-6975.

Breese C. R., Marks M. J., Logel J., Adams C. E., Sullivan B., Collins A. C. and Leonard S. (1997) Effect of smoking history on $\left[{ }^{3} \mathrm{H}\right]$ nicotine binding in human postmortem brain. J. Pharmacol. Exp. Ther. 282, 7-13.

Brini M., Marsault R., Bastianutto C., Alvarez J., Pozzan T. and Rizzuto R. (1995) Transfected aequorin in the measurement of cytosolic $\mathrm{Ca}^{2+}$ concentration $\left(\left[\mathrm{Ca}^{2+}\right] \mathrm{c}\right)$. A critical evaluation. J. Biol. Chem. 270, 9896-9903.

Buisson B. and Bertrand D. (2001) Chronic exposure to nicotine upregulates the human (alpha)4(beta)2 nicotinic acetylcholine receptor function. J. Neurosci. 21, 1819-1829.

Buisson B., Gopalakrishnan M., Arneric S. P., Sullivan J. P. and Bertrand D. (1996) Human alpha4beta2 neuronal nicotinic acetylcholine receptor in HEK 293 cells: A patch-clamp study. J. Neurosci. 16, 7880-7891.

Butt C. M., King N. M., Stitzel J. A. and Collins A. C. (2004) Interaction of the nicotinic cholinergic system with ethanol withdrawal. J. Pharmacol. Exp. Ther 308, 591-599.

Castro N. G. and Albuquerque E. X. (1995) Alpha-bungarotoxin-sensitive hippocampal nicotinic receptor channel has a high calcium permeability. Biophys. J. 68, 516-524. 
Champtiaux N., Han Z. Y., Bessis A., Rossi F. M., Zoli M., Marubio L., McIntosh J. M. and Changeux J. P. (2002) Distribution and pharmacology of alpha 6-containing nicotinic acetylcholine receptors analyzed with mutant mice. J. Neurosci. 22, 1208-1217.

Chavez-Noriega L. E., Gillespie A., Stauderman K. A. et al. (2000) Characterization of the recombinant human neuronal nicotinic acetylcholine receptors alpha3beta2 and alpha4beta2 stably expressed in HEK293 cells. Neuropharmacology 39, 2543-2560.

Clarke P. B. and Reuben M. (1996) Release of $\left[{ }^{3} \mathrm{H}\right]$-noradrenaline from rat hippocampal synaptosomes by nicotine: mediation by different nicotinic receptor subtypes from striatal $\left[{ }^{3} \mathrm{H}\right]$-dopamine release. Br. J. Pharmacol. 117, 595-606.

Dajas-Bailador F. A., Mogg A. J. and Wonnacott S. (2002) Intracellular $\mathrm{Ca}^{2+}$ signals evoked by stimulation of nicotinic acetylcholine receptors in SH-SY5Y cells: contribution of voltage-operated $\mathrm{Ca}^{2+}$ channels and $\mathrm{Ca}^{2+}$ stores. J. Neurochem. 81, 606-614.

Dobelis P., Marks M. J., Whiteaker P., Balogh S. A., Collins A. C. and Stitzel J. A. (2002) A polymorphism in the mouse neuronal alpha4 nicotinic receptor subunit results in an alteration in receptor function. Mol. Pharmacol. 62, 334-342.

Eaton J. B., Peng J. H., Schroeder K. M., George A. A., Fryer J. D., Krishnan C., Buhlman L., Kuo Y. P., Steinlein O. and Lukas R. J. (2003) Characterization of human alpha4beta2-nicotinic acetylcholine receptors stably and heterologously expressed in native nicotinic receptor-null SH-EP1 human epithelial cells. Mol. Pharmacol. 64, 1283-1294.

Epping-Jordan M. P., Picciotto M. R., Changeux J. P. and Pich E. M. (1999) Assessment of nicotinic acetylcholine receptor subunit contributions to nicotine self-administration in mutant mice. Psychopharmacology (Berl.) 147, 25-26.

Fitch R. W., Xiao Y., Kellar K. J. and Daly J. W. (2003) Membrane potential fluorescence: a rapid and highly sensitive assay for nicotinic receptor channel function. Proc. Natl Acad. Sci. USA 100, $4909-4914$.

Flynn D. D. and Mash D. C. (1986) Characterization of L- $\left[{ }^{3} \mathrm{H}\right]$ nicotine binding in human cerebral cortex: comparison between Alzheimer's disease and the normal. J. Neurochem. 47, 1948-1954.

Gafni J., Munsch J. A., Lam T. H., Catlin M. C., Costa L. G., Molinski T. F. and Pessah I. N. (1997) Xestospongins: potent membrane permeable blockers of the inositol 1,4,5-trisphosphate receptor. Neuron 19, 723-733.

Gopalakrishnan M., Monteggia L. M., Anderson D. J., Molinari E. J., Piattoni-Kaplan M., Donnelly-Roberts D., Arneric S. P. and Sullivan J. P. (1996) Stable expression, pharmacologic properties and regulation of the human neuronal nicotinic acetylcholine alpha4beta2 receptor. J. Pharmacol. Exp. Ther. 276, 289-297.

Grady S., Marks M. J., Wonnacott S. and Collins A. C. (1992) Characterization of nicotinic receptor-mediated $\left[{ }^{3} \mathrm{H}\right]$ dopamine release from synaptosomes prepared from mouse striatum. J. Neurochem. 59, 848-856.

Grady S. R., Grun E. U., Marks M. J. and Collins A. C. (1997) Pharmacological comparison of transient and persistent $\left[{ }^{3} \mathrm{H}\right]$ dopamine release from mouse striatal synaptosomes and response to chronic L-nicotine treatment. J. Pharmacol. Exp. Ther. 282, 32-43.

Gray R., Rajan A. S., Radcliffe K. A., Yakehiro M. and Dani J. A. (1996) Hippocampal synaptic transmission enhanced by low concentrations of nicotine. Nature 383, 713-716.

Gueorguiev V. D., Zeman R. J., Meyer E. M. and Sabban E. L. (2000) Involvement of alpha7 nicotinic acetylcholine receptors in activation of tyrosine hydroxylase and dopamine beta-hydroxylase gene expression in PC12 cells. J. Neurochem. 75, 1997-2005.

Kim H., Flanagin B. A., Qin C., Macdonald R. L. and Stitzel J. A. (2003) The mouse Chrna4 A529T polymorphism alters the ratio of high to low affinity alpha4beta2 nAChRs. Neuropharmacology 45, 345354.

Klink R., de Kerchove D. A., Zoli M. and Changeux J. P. (2001) Molecular and physiological diversity of nicotinic acetylcholine receptors in the midbrain dopaminergic nuclei. J. Neurosci. 21, $1452-1463$.

Lin L., Jeanclos E. M., Treuil M., Braunewell K. H., Gundelfinger E. D. and Anand R. (2002) The calcium sensor protein visinin-like protein-1 modulates the surface expression and agonist sensitivity of the alpha4beta2 nicotinic acetylcholine receptor. J. Biol. Chem. 277, $41872-41878$.

Lindstrom J. M. (2003) Nicotinic acetylcholine receptors of muscles and nerves: comparison of their structures, functional roles, and vulnerability to pathology. Ann. NY Acad. Sci. 998, 41-52.

Lowry O. H., Rosebrough N. H., Farr A. C. and Randall R. T. (1951) Protein measurement with the Folin phenol reagent. J. Biol. Chem. 193, 265-275.

Lu Y., Grady S., Marks M. J., Picciotto M., Changeux J. P. and Collins A. C. (1998) Pharmacological characterization of nicotinic receptor-stimulated GABA release from mouse brain synaptosomes. J. Pharmacol. Exp. Ther. 287, 648-657.

Marks M. J., Burch J. B. and Collins A. C. (1983) Effects of chronic nicotine infusion on tolerance development and nicotinic receptors. J. Pharmacol. Exp. Ther. 226, 817-825.

Marks M. J., Smith K. W. and Collins A. C. (1998) Differential agonist inhibition identifies multiple epibatidine binding sites in mouse brain. J. Pharmacol. Exp. Ther. 285, 377-386.

Marks M. J., Whiteaker P., Calcaterra J., Stitzel J. A., Bullock A. E., Grady S. R., Picciotto M. R., Changeux J. P. and Collins A. C. (1999) Two pharmacologically distinct components of nicotinic receptor-mediated rubidium efflux in mouse brain require the beta2 subunit. J. Pharmacol. Exp. Ther. 289, 1090-1103.

Michelmore S., Croskery K., Nozulak J., Hoyer D., Longato R., Weber A., Bouhelal R. and Feuerbach D. (2002) Study of the calcium dynamics of the human alpha4beta2, alpha3beta4 and alphalbeta1gammadelta nicotinic acetylcholine receptors. Naunyn Schmiedebergs Arch. Pharmacol. 366, 235-245.

Mogg A. J., Whiteaker P., McIntosh J. M., Marks M., Collins A. C. and Wonnacott S. (2002) Methyllycaconitine is a potent antagonist of alpha-conotoxin-MII-sensitive presynaptic nicotinic acetylcholine receptors in rat striatum. J. Pharmacol. Exp. Ther. 302, 197-204.

Nayak S. V., Dougherty J. J., McIntosh J. M. and Nichols R. A. (2001) $\mathrm{Ca}(2+)$ changes induced by different presynaptic nicotinic receptors in separate populations of individual striatal nerve terminals. J. Neurochem. 76, 1860-1870.

Nelson M. E., Kuryatov A., Choi C. H., Zhou Y. and Lindstrom J. (2003) Alternate stoichiometries of alpha4beta2 nicotinic acetylcholine receptors. Mol. Pharmacol. 63, 332-341.

Nordberg A. and Winblad B. (1986) Reduced number of $\left[{ }^{3} \mathrm{H}\right]$ nicotine and $\left[{ }^{3} \mathrm{H}\right]$ acetylcholine binding sites in the frontal cortex of Alzheimer brains. Neurosci. Lett. 72, 115-119.

Owens J. C., Balogh S. A., McClure-Begley T. D., Butt C. M., Labarca C., Lester H. A., Picciotto M. R., Wehner J. M. and Collins A. C. (2003) Alpha4beta2* nicotinic acetylcholine receptors modulate the effects of ethanol and nicotine on the acoustic startle response. Alcohol Clin. Exp. Res. 27, 1867-1875.

Ozaki H., Hori M., Kim Y. S., Kwon S. C., Ahn D. S., Nakazawa H., Kobayashi M. and Karaki H. (2002) Inhibitory mechanism of xestospongin- $\mathrm{C}$ on contraction and ion channels in the intestinal smooth muscle. Br. J. Pharmacol. 137, 1207-1212.

Pacheco M. A., Pastoor T. E., Lukas R. J. and Wecker L. (2001) Characterization of human alpha4beta2 neuronal nicotinic receptors stably expressed in SH-EP1 cells. Neurochem. Res. 26, 683693. 
Palma E., Bertrand S., Binzoni T. and Bertrand D. (1996) Neuronal nicotinic alpha 7 receptor expressed in Xenopus oocytes presents five putative binding sites for methyllycaconitine. J. Physiol. 491, 151-161.

Picciotto M. R., Zoli M., Lena C., Bessis A., Lallemand Y., LeNovere N., Vincent P., Pich E. M., Brulet P. and Changeux J. P. (1995) Abnormal avoidance learning in mice lacking functional highaffinity nicotine receptor in the brain. Nature 374, 65-67.

Ragozzino D., Barabino B., Fucile S. and Eusebi F. (1998) $\mathrm{Ca}^{2+}$ permeability of mouse and chick nicotinic acetylcholine receptors expressed in transiently transfected human cells. J. Physiol. 507, 749-757.

Rapier C., Lunt G. G. and Wonnacott S. (1990) Nicotinic modulation of $\left[{ }^{3} \mathrm{H}\right]$ dopamine release from striatal synaptosomes: pharmacological characterisation. J. Neurochem. 54, 937-945.

Role L. W. and Berg D. K. (1996) Nicotinic receptors in the development and modulation of CNS synapses. Neuron 16, 1077-1085.

Ryan R. E., Ross S. A., Drago J. and Loiacono R. E. (2001) Dose-related neuroprotective effects of chronic nicotine in 6-hydroxydopamine treated rats, and loss of neuroprotection in alpha4 nicotinic receptor subunit knockout mice. Br. J. Pharmacol. 132, 1650-1656.

Salminen O. S., Murphy K. L., McIntosh J. M., Drago J., Marks M. J., Collins A. C. and Grady S. R. (2004) Subunit composition and pharmacology of two classes of striatal presynaptic nicotinic acetylcholine receptors mediating dopamine release in mice. Mol. Pharmacol. 65, 1526-1535.

Seguela P., Wadiche J., Dineley-Miller K., Dani J. A. and Patrick J. W. (1993) Molecular cloning, functional properties, and distribution of rat brain alpha 7: a nicotinic cation channel highly permeable to calcium. J. Neurosci. 13, 596-604.

Shafaee N., Houng M., Truong A., Viseshakul N., Figl A., Sandhu S., Forsayeth J. R., Dwoskin L. P., Crooks P. A. and Cohen B. N. (1999) Pharmacological similarities between native brain and heterologously expressed alpha4beta2 nicotinic receptors. Br. J. Pharmacol. 128, 1291-1299.

Sharma G. and Vijayaraghavan S. (2001) Nicotinic cholinergic signaling in hippocampal astrocytes involves calcium-induced calcium release from intracellular stores. Proc. Natl Acad. Sci. USA 98, $4148-4153$.

Shoop R. D., Chang K. T., Ellisman M. H. and Berg D. K. (2001) Synaptically driven calcium transients via nicotinic receptors on somatic spines. J. Neurosci. 21, 771-781.

Steinlein O. K. (2004) Nicotinic receptor mutations in human epilepsy. Prog. Brain Res. 145, 275-285.

Stitzel J. A., Jimenez M., Marks M. J., Tritto T. and Collins A. C. (2000) Potential role of the alpha4 and alpha6 nicotinic receptor subunits in regulating nicotine-induced seizures. J. Pharmacol. Exp. Ther. 293, 67-74.

Stitzel J. A., Dobelis P., Jimenez M. and Collins A. C. (2001) Long sleep and short sleep mice differ in nicotine-stimulated ${ }^{86} \mathrm{Rb}^{+}$efflux and alpha4 nicotinic receptor subunit cDNA sequence. Pharmacogenetics 11, 331-339.
Tritto T., Stitzel J. A., Marks M. J., Romm E. and Collins A. C. (2002) Variability in response to nicotine in the LSxSS RI strains: potential role of polymorphisms in alpha4 and alpha6 nicotinic receptor genes. Pharmacogenetics 12, 197-208.

Truong A., Xing X., Forsayeth J. R., Dwoskin L. P., Crooks P. A. and Cohen B. N. (2001) Pharmacological differences between immunoisolated native brain and heterologously expressed rat alpha4beta2 nicotinic receptors. Brain Res. Mol. Brain Res. 96, 68-76.

Tsuneki H., Klink R., Lena C., Korn H. and Changeux J. P. (2000) Calcium mobilization elicited by two types of nicotinic acetylcholine receptors in mouse substantia nigra pars compacta. Eur. $J$. Neurosci. 12, 2475-2485.

Ungrin M. D., Singh L. M., Stocco R., Sas D. E. and Abramovitz M. (1999) An automated aequorin luminescence-based functional calcium assay for G-protein-coupled receptors. Anal. Biochem. 272, 34-42.

Vernino S., Amador M., Luetje C. W., Patrick J. and Dani J. A. (1992) Calcium modulation and high calcium permeability of neuronal nicotinic acetylcholine receptors. Neuron 8, 127-134.

Vernon W. I. and Printen J. A. (2002) Assay for intracellular calcium using a codon-optimized aequorin. Biotechniques 33, 730-734.

Virginio C., Giacometti A., Aldegher L., Rimland J. M. and Terstappen G. C. (2002) Pharmacological properties of rat alpha 7 nicotinic receptors expressed in native and recombinant cell systems. Eur. $J$. Pharmacol. 445, 153-161.

Whitehouse P. J., Martino A. M., Antuono P. G., Lowenstein P. R., Coyle J. T., Price D. L. and Kellar K. J. (1986) Nicotinic acetylcholine binding sites in Alzheimer's disease. Brain Res. 371, 146-151.

Whiting P. J. and Lindstrom J. M. (1988) Characterization of bovine and human neuronal nicotinic acetylcholine receptors using monoclonal antibodies. J. Neurosci. 8, 3395-3404.

Xiao Y., Meyer E. L., Thompson J. M., Surin A., Wroblewski J. and Kellar K. J. (1998) Rat alpha3/beta4 subtype of neuronal nicotinic acetylcholine receptor stably expressed in a transfected cell line: pharmacology of ligand binding and function. Mol. Pharmacol. 54, 322-333.

Zanello L. P., Aztiria E., Antollini S. and Barrantes F. J. (1996) Nicotinic acetylcholine receptor channels are influenced by the physical state of their membrane environment. Biophys. J. 70, 2155-2164.

Zhou Y., Nelson M. E., Kuryatov A., Choi C., Cooper J. and Lindstrom J. (2003) Human alpha4beta2 acetylcholine receptors formed from linked subunits. J. Neurosci. 23, 9004-9015.

Zhu P. J. and Chiappinelli V. A. (1999) Nicotine modulates evoked GABAergic transmission in the brain. $J$. Neurophysiol. 82, 30413045.

Zoli M., Moretti M., Zanardi A., McIntosh J. M., Clementi F. and Gotti C. (2002) Identification of the nicotinic receptor subtypes expressed on dopaminergic terminals in the rat striatum. $J$. Neurosci. 22, 8785-8789.

Zwart R. and Vijverberg H. P. (1998) Four pharmacologically distinct subtypes of alpha4beta2 nicotinic acetylcholine receptor expressed in Xenopus laevis oocytes. Mol. Pharmacol. 54, 1124-1131. 